\title{
Solution scanning as a key policy tool: identifying management interventions to help maintain and enhance regulating ecosystem services
}

\author{
William J. Sutherland ${ }^{1}$, Toby Gardner ${ }^{1}$, Tiffany L. Bogich ${ }^{2}$, Richard B. Bradbury ${ }^{3}$, Brent Clothier ${ }^{4}$, Mattias Jonsson ${ }^{5}$, Val Kapos ${ }^{6}$, \\ Stuart N. Lane ${ }^{7}$, Iris Möller ${ }^{8}$, Martin Schroeder ${ }^{5}$, Mark Spalding $^{9}$, Tom Spencer $^{8}$, Piran C. L. White $^{10}$ and Lynn V. Dicks ${ }^{1}$
}

\begin{abstract}
The major task of policy makers and practitioners when confronted with a resource management problem is to decide on the potential solution(s) to adopt from a range of available options. However, this process is unlikely to be successful and cost effective without access to an independently verified and comprehensive available list of options. There is currently burgeoning interest in ecosystem services and quantitative assessments of their importance and value. Recognition of the value of ecosystem services to human well-being represents an increasingly important argument for protecting and restoring the natural environment, alongside the moral and ethical justifications for conservation. As well as understanding the benefits of ecosystem services, it is also important to synthesize the practical interventions that are capable of maintaining and/or enhancing these services. Apart from pest regulation, pollination, and global climate regulation, this type of exercise has attracted relatively little attention. Through a systematic consultation exercise, we identify a candidate list of 296 possible interventions across the main regulating services of air quality regulation, climate regulation, water flow regulation, erosion regulation, water purification and waste treatment, disease regulation, pest regulation, pollination and natural hazard regulation. The range of interventions differs greatly between habitats and services depending upon the ease of manipulation and the level of research intensity. Some interventions have the potential to deliver benefits across a range of regulating services, especially those that reduce soil loss and maintain forest cover. Synthesis and applications: Solution scanning is important for questioning existing knowledge and identifying the range of options available to researchers and practitioners, as well as serving as the necessary basis for assessing cost effectiveness and guiding implementation strategies. We recommend that it become a routine part of decision making in all environmental policy areas.
\end{abstract}

Key Words: Climate regulation; policy making; pollination; regulating services; solution scanning; water regulation

\section{INTRODUCTION}

The first stage in policy development is to identify a problem or a need for new policy. This can be done through horizon scanning to identify novel issues (Sutherland et al. 2013) or threats relating to a particular issue (Sutherland et al. 2012) or by identifying opportunities for policy development (Sutherland et al. 2010). Once a need for new policy is identified and the problem to be dealt with has been framed, then policy makers, whether working on education, road safety, social mobility, illegal drugs, or wildlife conservation, are invariably faced with a large range of possible policy options. Policies typically arise from some amalgamation of the ideas and beliefs of politicians, the experience of those responsible for creating or delivering policy, and external bodies seeking to have their agenda adopted (Jasanoff 1994). Science is then often used to help bolster or reject established positions rather than as an objective means of assessing the available evidence (Sarewitz 2000, Lawton 2007).

An alternative and more rigorous strategy, which we term here "solution scanning," is to list all the known possibilities for addressing a particular problem, or set of problems, before considering the evidence for and practicalities of recommending their adoption in a particular context (Fig. 1). A strategic and comprehensive identification of possible solutions has the advantage that it encourages consideration of a wide range of possibilities before focusing on only one, or a subset. It also makes explicit which options have been discarded in subsequent stepsa key aspect of a truly transparent decision-making process. Although it would be ideal to have access to a comprehensive review of the evidence base for all available policy options, merely identifying the full set of options that are available can be an invaluable, and considerably cheaper and quicker, first step. This is especially the case for complex and multifaceted policy problems, where multiple problems are being addressed, where the range of interventions that could influence desired outcomes is considerable, and where the desired outcomes may be location or context specific.

Over recent years, a huge policy and research interest has developed around the subjects of natural capital and ecosystem services (Seppelt et al. 2011). Much of the research effort so far in developing the "ecosystem service approach" has focused on techniques for monitoring and assessment (Seppelt et al. 2012), ways of quantifying service production and use for economic valuation purposes (Daily et al. 2000, Fisher and Turner 2008, Fisher et al. 2009, Dominati et al. 2010, Raudsepp-Hearne et al. 2010, Robinson and Lebron 2010, Kareiva et al. 2011, Bateman et al. 2013), identifying status and trends (Hassan et al. 2005, UK National Ecosystem Assessment 2011), or considering impacts and trade-offs between services (Chan et al. 2006, Zhang et al.

\footnotetext{
${ }^{1}$ Conservation Science Group, Department of Zoology, University of Cambridge, ${ }^{2}$ Princeton University, Ecology \& Evolutionary Biology, ${ }^{3}$ Conservation Science Department, Royal Society for the Protection of Birds, ${ }^{4}$ New Zealand Plant \& Food Research, Climate Lab, ${ }^{5}$ Department of Ecology, Swedish University of Agricultural Sciences, ${ }^{6}$ United Nations Environment Programme World Conservation Monitoring Centre, ${ }^{7}$ Institute of Hazard, Risk and Resilience, Science Laboratories, ${ }^{8}$ Cambridge Coastal Research Unit, Department of Geography, University of Cambridge, ${ }^{9}$ The Nature Conservancy and Conservation Science Group, Department of Zoology, University of Cambridge, ${ }^{10}$ Environment Department, University of York
} 
Fig. 1. A conceptual process diagram for making policy or management decisions. Six stages of decision making are described (solid-line rectangles), moving from horizon scanning of problems through solution scanning, assessment of evidence and monitoring effectiveness of selected interventions. Solution scanning, demonstrated here for regulating ecosystem services, is stage three. Between each stage and the subsequent stage, there is a filtering process in which some elements are removed according to priorities set by decision makers or relevant sections of wider society. At each stage, there should be some reflection of how well the process is working to inform future activities in one or more previous stages (solid arrows). Making the selection and prioritization processes inherent to each step more explicit provides an opportunity for research to make a more transparent, rigorous, and defensible contribution to decision making.

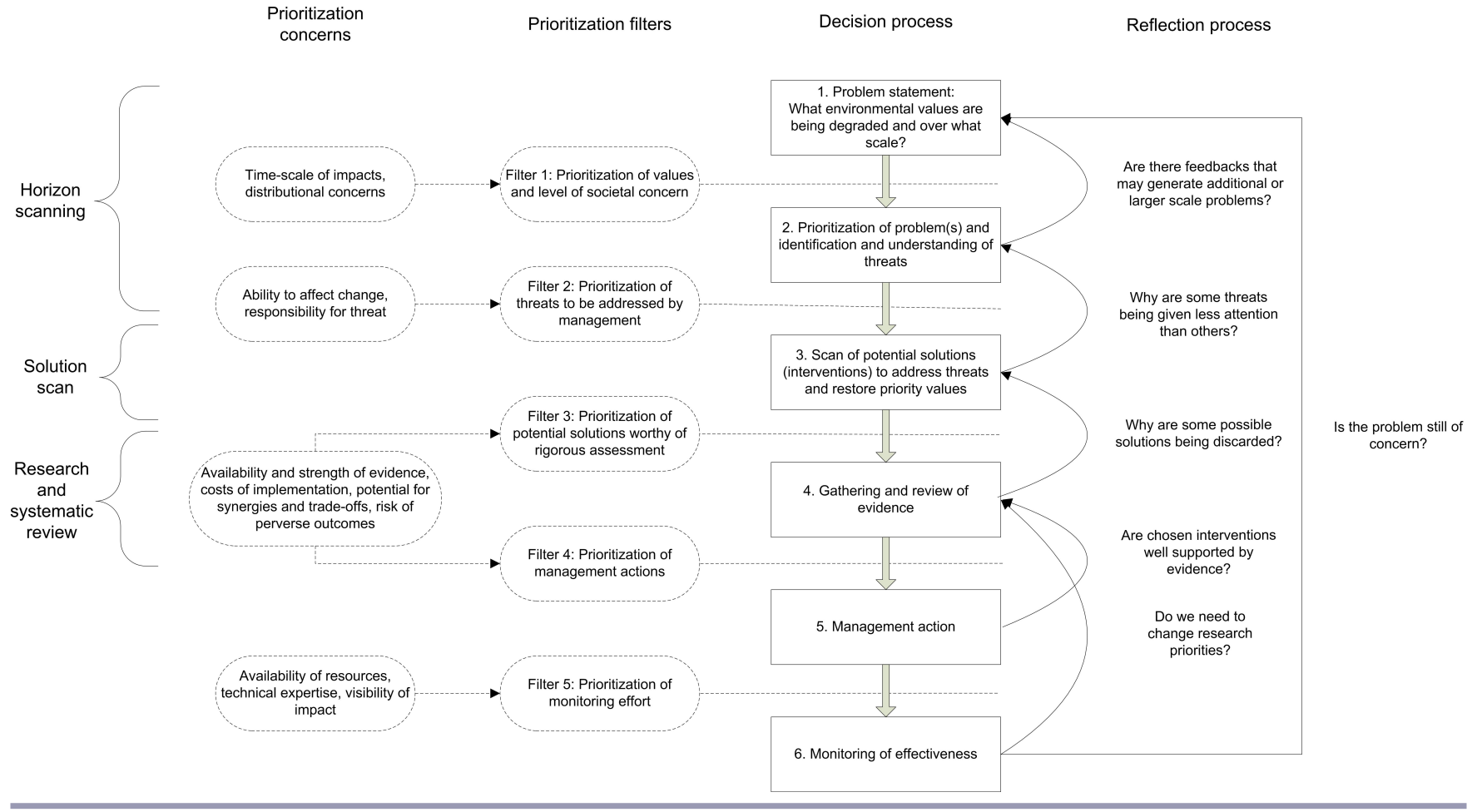

2007, Barton et al. 2009, Bennett et al. 2009, Nelson et al. 2009, Chisholm 2010). The importance of biodiversity and functional diversity in underpinning ecosystem function and service provision has also been highlighted (e.g., Beaumont et al. 2007, Loreau 2010, The Economics of Ecosystems and Biodiversity (TEEB) 2010). Ecosystem services have become a major component of the justification for the conservation of nature. Maintaining, enhancing, and restoring ecosystem services, through improving ecological coherence and connectedness, have become a high-level policy goal (Department for Environment, Food and Rural Affairs (DEFRA) 2011, European Commission 2011, World Bank 2012). However, there has been much less research emphasis on identifying the most effective means by which this can be achieved.

Research has greatly increased our understanding of the importance of ecosystem services. For this to make a difference to the state of the environment, it needs to influence decision making and alter the ways people use and manage ecosystems. In particular, it is imperative to understand how different ways of managing any given aspect of the environment may influence net changes in the provision of multiple, but potentially competing and/or synergistic services (e.g., Pilgrim et al. 2010, Posthumus et al. 2010), including within multifunctional landscapes (Reyers et al. 2012). A first and very practical step toward developing such an understanding is to generate a simple list of potential "solutions", or interventions (Jacquet et al. 2011) that could deliver favorable outcomes for ecosystem service conservation. Such a listing or scanning exercise has value if undertaken in a systematic and rigorous way.

Figure 1 illustrates how the solution scan proposed here sits within a wider decision-making process. We identify five stages of the decision process and identify the prioritization filters that could be imposed at each stage to narrow down options for a specific context and scale. The first two stages are concerned with identifying and framing problems and are encompassed by what is traditionally termed horizon scanning, as described above. The next stage is the solution scan presented here. Following the solution scan is the process of reviewing evidence, in which effectiveness, costs, synergies, and trade-offs should be taken into account. Selected actions are then implemented and can be monitored.

In this paper, we aim to provide a comprehensive list of possible interventions and investments that can enhance ecological 
infrastructural capacity and positively influence the conservation of the range of regulating ecosystem services identified by the Millennium Ecosystem Assessment (Hassan et al. 2005). We limit our focus to regulating services: air quality regulation, climate regulation, water regulation, erosion regulation, water purification, water and waste treatment, disease regulation, pest regulation, and pollination and natural hazard regulation. Regulating services provide capacity for the ecosystem to adapt to short-term disturbances and longer-term change, and therefore play a fundamental role in protecting human livelihoods and wellbeing (Carpenter et al. 2006). They are particularly important for cross-sectoral policy development, as their degradation can lead to increased exposure of the human population to physical hazards, such as land erosion, flooding, or crop yield loss, for which expensive human-engineered solutions may provide the only alternative mitigation. Indeed, some regulating services are not substitutable by current technology. Regulating services are also a useful place to start in developing policy decisions on how to manage for ecosystem services, because there is some evidence that they are representative of a wider set of ecosystem services that tend to trade off against the provisioning services, such as food or timber production. Raudsepp-Hearne et al. (2010) showed that, at landscape scale in Quebec, Canada, regulating services trade off against provisioning services such as food, wood or fiber production, but correlate positively with the diversity of cultural (such as esthetic, spiritual, educational, and recreational) benefits, and supporting ecosystem services (such as nutrient cycling, soil formation, and primary production).

Although we do not consider provisioning, cultural benefits, and supporting ecosystem services here, we believe it would be valuable to take a similar approach and list potential solutions to maintain or enhance these.

\section{METHODS}

The listing exercise was conducted by email using established processes for collecting the expertise of a group of experts (Sutherland et al. 2011a). We selected a group of experts with extensive knowledge of a range of aspects of ecosystem service research and management. These experts are the authors of this paper. The initial list of solutions or interventions for each type of regulating service was compiled by an expert in that specific area of ecosystem service research and management and then circulated to the full team of authors for revision and expansion. There was considerable, and iterative, discussion by email as to whether certain interventions or classes of interventions should be included. The authors also consulted widely to try to reduce omissions from the draft list. The near-final draft was circulated within various organizations and among other experts for further input.

Such a list can always be added to. It is especially likely to miss novel and obscure interventions. We stress that although all the solutions are presented in the same manner and without qualification, they may differ in the scale of their impacts. Some may be controversial (e.g., ocean fertilization) or unlikely to be successful (e.g., coastal habitat creation in locations that have not previously supported such habitats). Others may have important negative consequences. For example, decreasing the level of landuse intensity through large-scale conversion to lower-yield organic farming could exacerbate loss of natural habitats through a requirement for greater land area (Hodgson et al. 2010).
We have focused efforts on considering the nature of on-theground management interventions rather than the mechanisms by which they are achieved. We do not include large-scale pollution mitigation measures, such as alternative energy or fuelefficient transportation, whose implementation is at a much larger scale than the operational management of ecosystems. Neither do we include any interventions aimed at changing market or consumer behavior. For example, we describe the means of storing carbon in ecosystems but not the option of paying for carbon storage. We consider this approach to be most useful from the perspective of those people responsible for managing ecosystems in policy or practice. That said, it may be profitable to develop a separate solution scan to assess the potential policy options that can be used to change market or consumer behavior.

\section{RESULTS}

Appendix 1 gives the 296 suggested solutions identified for retaining or enhancing regulating ecosystem services, organized by the major habitat types: forest, terrestrial wetland, freshwater, coastal, marine, agricultural land, and urban. Table 1 classifies the interventions according to both the broad habitat and the type of regulating ecosystem service likely to be enhanced. It shows that relatively few management interventions were identified to benefit air quality or enhance regulation of diseases, whereas there are many ways of improving regulation of erosion or natural hazards. The interventions also differ markedly across habitats: few solutions were identified for marine habitats, but agricultural land has the highest number of interventions. This is presumably because it is easier to devise and implement new land-use and management practices in agricultural land that is already heavily managed.

The solution scan provides an easy way to begin assessing the extent to which interventions might provide benefits across multiple ecosystem services. In Table 2, we list 17 interventions, or classes of intervention, that enhance multiple (three or more) regulating ecosystem services. One of these interventions, "Use measures for reducing soil loss (such as cover crops and reduced tillage)," was identified as beneficial for eight of the nine regulating ecosystem services.

\section{DISCUSSION}

This exercise shows that there is a considerable range of possible solutions for maintaining and enhancing regulating ecosystem services. By its very nature, this kind of list will never be fully comprehensive. There are expected to be some biases in the range of interventions included and the level of detail, according to the expertise of the people involved in drawing up the list. Our list of interventions was informed by a limited set of experts from mostly western European institutions, with the inevitable biases that this introduces. More tailored solution scans for specific regions and environmental problems could be drawn up by combined groups involving local researchers and people actually managing ecosystem services or benefiting from them, such as the "ecosystem stewards" defined by Schultz et al. (2007).

The solution scan as presented here does not indicate the expected cost effectiveness of any given intervention. Figure 1 shows the subsequent steps and considerations that will be required to move from an initial solution scan to a plan of action for enhancing regulating ecosystem services in a given landscape. Consideration of cost effectiveness, as well as the identification of possible risks 
Table 1. Numbers of interventions identified to enhance regulating ecosystem services, classified according to broad habitat and type of regulating ecosystem service.

\begin{tabular}{|c|c|c|c|c|c|c|c|c|}
\hline & Forests & $\begin{array}{l}\text { Terrestrial } \\
\text { wetlands }\end{array}$ & Freshwater & Coastal & Marine & Agricultural & Urban & Total \\
\hline Air quality & 1 & & & 1 & & 2 & 1 & 5 \\
\hline Climate regulation & 4 & 8 & & 9 & 1 & 14 & 1 & 37 \\
\hline Water flow & 6 & 5 & 5 & 1 & & 13 & 4 & 34 \\
\hline Erosion & 6 & 4 & 7 & 22 & & 15 & 2 & 56 \\
\hline Water purification & & 6 & & 4 & 1 & 8 & 4 & 23 \\
\hline Disease regulation & 3 & & & 1 & & 9 & 5 & 18 \\
\hline Pest regulation & $15^{\dagger}$ & & & & & $30^{\dagger}$ & & $45^{\dagger}$ \\
\hline Pollination & 5 & & & & & 24 & 2 & 31 \\
\hline $\begin{array}{l}\text { Natural hazard } \\
\text { regulation }\end{array}$ & 5 & 7 & 5 & 15 & & 9 & 6 & 47 \\
\hline Total & 45 & 30 & 17 & 53 & 2 & 124 & 25 & 296 \\
\hline
\end{tabular}

${ }^{\dagger}$ The habitats given for this service are where the service is delivered. Some interventions include measures that can be taken in the landscape surrounding these habitats.

and the potential for undesirable outcomes, is central to this wider process.

Effectiveness will vary according to circumstance and geographic context and will depend on the presence or absence of other facilitating or exacerbating factors. The research and systematic review part of the process (moving from stage 3 to stage 5 in Fig. 1) requires a thorough assessment of the evidence for the most promising interventions or sets of interventions (Sutherland et al. 2004). Ideally, this will involve systematic reviews of evidence for individual interventions (Munroe et al. 2012, Pullin et al. 2013), combined with synopses that collate evidence relating to all interventions on a topic. The synopsis approach has recently been applied to all known interventions to conserve wild bees (Dicks et al. 2010) and birds (Williams et al. 2013) globally. The research and review process could also involve eliciting expert judgement where published data are sparse or time is short (Martin et al. 2012), or using expert judgement to evaluate a complex evidence base (Dicks et al. 2013).

There is a strong tendency in both policy and research to jump from stage 2 (Prioritization of problem) to stage 4 (Gathering and review of evidence) without a solution-scanning stage. When this happens, the choice of interventions to cover is not the primary purpose of the reviewing exercise, and so the list of interventions tends not to be so thorough as one generated by a dedicated and collaborative solution scan. For example, Kremen and Miles (Kremen and Miles 2012) reviewed evidence for effects of diversified farming systems on the delivery of various ecosystem services. Everything in the list of farm or landscape-scale management interventions they used as the basis for their search protocol is included in our solution scan, but there are additional options in our list that are also part of diversified farming systems. For example, reduced livestock stocking rates and reduced use of agrochemicals appear several times in the agricultural land sections of our list (Appendix 1), but were not incorporated into the literature search of Kremen and Miles (2012).

Some of the interventions included in Appendix 1, such as reduced agrochemical use and coastal protection, are well studied.
Others, such as the use of biochar and the use of new technologies for cleaning up waste or pollution, are more novel and much less well researched. Filtering out interventions that are inappropriate in a given context or geographic region (Filters 3 and 4 in Fig. 1) will be influenced by limitations on resources and technical expertise necessary for their implementation, as well as by the available knowledge on cost effectiveness.

Although options in this list are presented as individual interventions, in reality they are often not independent, as there can be conflicts or synergies among them (Bradbury et al. 2010, Fisher et al. 2011). As we have shown, certain interventions are likely to provide benefits across multiple ecosystem services (Table 2 ), with both forest protection and soil conservation considered likely to enhance a wide range of regulating ecosystem services. These types of intervention should, therefore, be particularly attractive as solutions for ecosystem service conservation in general. Many of the same interventions would also provide additional provisioning, cultural, or supporting services such as improvements in fisheries or recreational opportunities, and similar listings of these services would be an important contribution for future planning. In a given local context, there may also be synergies between management interventions to support ecosystem services and existing or planned management being carried out for other purposes, such as habitat conservation or recreation.

Conflicts or trade-offs are likely to occur. For example, there is an obvious conflict between intervention number 175 ("Increase resistance of trees by forest management (e.g., thinning for bark beetle pests)" and 184 ("Avoid thinning to reduce the risk of infestation of the stand by pathogens (e.g., root rot)") in Appendix 1. Both are recommended to enhance pest regulation in forests. As an example of trade-offs generated between different regulating services, tree planting (as in intervention 8 , "Reforest degraded land and encourage benign abandonment of low productivity or disused land" for example) may increase carbon stocks above ground, but at the same time reduce water recharge rates to aquifers (Dye 1996). In such cases, the appropriate 
Table 2. Management interventions that enhance multiple (three or more) regulating ecosystem services. Numbers in square brackets identify specific interventions listed in Appendix 1. Note that in some cases, such as for soil conservation measures, specific interventions are described slightly differently for different ecosystem services and have been grouped together here (see Appendix 1).

\begin{tabular}{|c|c|c|c|c|c|c|c|c|c|c|}
\hline Type of intervention & $\begin{array}{l}\text { Air } \\
\text { quality } \\
\text { regulation }\end{array}$ & $\begin{array}{l}\text { Climate } \\
\text { regulation }\end{array}$ & $\begin{array}{l}\text { Water flow } \\
\text { regulation }\end{array}$ & $\begin{array}{l}\text { Erosion } \\
\text { regulation }\end{array}$ & $\begin{array}{l}\text { Water } \\
\text { purification }\end{array}$ & $\begin{array}{l}\text { Disease } \\
\text { regulation }\end{array}$ & $\begin{array}{l}\text { Pest } \\
\text { regulation }\end{array}$ & Pollination & $\begin{array}{l}\text { Hazard } \\
\text { regulation }\end{array}$ & $\begin{array}{l}\text { Number } \\
\text { of } \\
\text { regulating } \\
\text { service } \\
\text { types }\end{array}$ \\
\hline Plant shelter belts, hedges, trees & {$[3]$} & & [63] & [123] & {$[144]$} & & [214] & {$[227]$} & [282] & 7 \\
\hline $\begin{array}{l}\text { Use measures for reducing soil loss } \\
\text { (such as cover crops and reduced } \\
\text { tillage) }\end{array}$ & [4] & {$[28]$} & {$[60]$} & [116-120] & & [161] & [201] & [237] & [283] & 8 \\
\hline Increase soil organic matter & & [34] & [61] & & [148] & & [205] & & [284] & 5 \\
\hline Reduce soil compaction & & & {$[43,65-66]$} & {$[122]$} & & & & & [287-288] & 3 \\
\hline Reduce stocking rates of livestock & & [35] & [64] & {$[126]$} & & {$[162]$} & & & [286] & 5 \\
\hline Revegetate bare peat & & {$[12]$} & {$[51]$} & {$[84]$} & [138] & & & & & 4 \\
\hline Use geo-textiles to arrest peat erosion & & [13] & {$[52]$} & {$[85]$} & & & & & & 3 \\
\hline Promote urban green infrastructure & {$[5]$} & {$[42]$} & [73] & & & {$[171]$} & & & [293-294] & 5 \\
\hline $\begin{array}{l}\text { Protect, restore, and create intertidal } \\
\text { habitats }\end{array}$ & & {$[18,19,22]$} & & {$[94-95,98]$} & {$[139-140]$} & & & & [267-269] & 4 \\
\hline Protect and expand forests & {$[1]$} & {$[6]$} & {$[44]$} & {$[77,97]$} & & {$[157]$} & & [219] & {$[250,253,258]$} & 7 \\
\hline Practice continuous cover forestry & & & [48] & {$[82]$} & & & {$[177]$} & & & 3 \\
\hline $\begin{array}{l}\text { Improve landscape-scale connectivity } \\
\text { between natural or non-crop habitat } \\
\text { remnants }\end{array}$ & & & & & & [166] & [213] & [230] & & 3 \\
\hline Reduce pesticide/insecticide use & & [40] & & & & & {$[202,203]$} & {$[240,242]$} & & 3 \\
\hline Maintain and enhance natural wetlands & {$[2]$} & {$[10]$} & [49] & [99] & & [159] & & & {$[256]$} & 6 \\
\hline $\begin{array}{l}\text { Install dams in surface drains on } \\
\text { wetlands }\end{array}$ & & [11] & & {$[83,130]$} & & & & & [257] & 3 \\
\hline Revegetate river banks & & & {$[54]$} & {$[78,87]$} & & & & & [262] & 3 \\
\hline $\begin{array}{l}\text { Increase structural/channel diversity in } \\
\text { rivers }\end{array}$ & & & {$[56,57]$} & {$[88,90]$} & & & & & {$[264,265]$} & 3 \\
\hline $\begin{array}{l}\text { Number of interventions that may have } \\
\text { synergistic benefits for other regulating } \\
\text { services }\end{array}$ & 5 & 13 & 16 & 23 & 5 & 6 & 7 & 6 & 19 & \\
\hline
\end{tabular}

solution will depend on the detailed environmental and socioeconomic context in which the decision is made. In these examples, the tree species being grown, the prevalent tree pathogens in the area, or the importance of aquifer recharge rates to the delivery of clean water for local communities seem likely to be important considerations. What is known about the effectiveness and relative costs of the conflicting solutions will also be important. A thorough assessment of potential synergies and trade-offs is clearly the next step in determining options for management, following this initial solution-scanning step (see Fig. 1, Stage 4, Filters 3 and 4). Nevertheless, a key strength of the solution-scanning approach is that it encourages recognition of as many interventions as possible, thus helping to ensure that any subsequent prioritization is transparent and defensible.

\section{Applications of this Approach}

We believe that the straightforward listing of possible solutions can help simplify both research and practice. We envisage three main ways in which solution scanning can be used. The main application is to provide a resource for policy makers and practitioners who need swiftly to decide which interventions to carry out from all available options. This allows them to ensure they have considered a full set of possibilities before coming to decisions based on available evidence, resources and technical expertise, local priorities, and synergies with existing management. To this end, the results of papers such as this one should be widely and effectively disseminated beyond academic circles. Solution scans and the subsequent prioritization processes presented here may be particularly useful in meeting the demands of high-level science policy processes like the Intergovernmental Panel on Biodiversity and Ecosystem Services (Pe'er et al. 2013), especially because, when carried out at the regional level, they offer an opportunity to incorporate traditional and indigenous knowledge. Second, such a scan provides an important input to setting research agendas for further studies, based on synthesis of evidence (Sutherland et al. 2004, Dicks et al. 2010, Sutherland et al. 2011b) and expert evaluation of evidence for policy questions (Dicks et al. 2013). Finally, making options explicit encourages other practitioners and researchers to identify possible interventions that may have been omitted from the original listing - ensuring that the process is dynamic and evolving.

One means of evaluating the effectiveness of specific interventions listed here is through the development of tailored monitoring tools that allow researchers to monitor changes in the provision of ecosystem services, either directly or via the benefits humans derive from them (Fisher et al. 2009). Combining measures of change in ecosystem health with information that characterizes different interventions, such as cost, would allow the application of formal analytical techniques for evaluation, such as cost-effectiveness and cost-utility analysis (Laycock et al. 2009). Once assessments have been made of the impacts of each intervention on a range of ecosystem services, synergies, trade-offs, and off-site effects can be highlighted. This information can then be used, in conjunction with other local considerations, to develop management strategies to deliver multifunctional landscapes (e.g., Turner et al. 2008, 
Haaland et al. 2011, Gulickx et al. 2013). Analytical techniques and frameworks, such as portfolio analysis (Bryan 2010), multiattribute decision analysis (Prato 1999), assessment of ecosystem service bundles (Raudsepp-Hearne et al. 2010), or GISlinked modeling (Nemec and Raudsepp-Hearne 2013, Burkhard et al. 2012) will also be important in highlighting ecosystem service interactions and informing landscape-scale management decisions.

This exercise has focused on actual physical interventions and investments in ecological infrastructures, rather than on the wider social, economic, political, or judicial mechanisms by which they might be achieved. Many of the interventions listed could be carried out by individuals or organizations wishing to reduce their environmental impact. They could be encouraged through incentives, such as payments, or disincentives, such as taxation or legislation. Some are possible through changes in individual behavior, whereas others demand collective action. Some interventions, especially those that could be brought about by simple changes in behavior, could be encouraged through education to promote greater awareness of environmental issues. When considering the effectiveness and efficiency of various solutions in a local context, it is essential to understand the policy, delivery, and institutional frameworks that could affect them. These would include considerations of legal context, the power and legitimacy of different stakeholder groups, local decision-making processes, and the opportunities presented by existing legislative and regulatory processes. Broader economic analyses will also be of critical value. These will require not only an understanding of the economic costs of interventions, but also of alternatives, such as the use of engineered (nonecosystem) solutions for flood defence or erosion reduction. Devising general guidelines for the most appropriate sets of mechanisms for delivering these interventions at different spatial and temporal scales, taking into account these broader considerations, is a priority area for further research. One worthwhile future exercise would be to develop and link a parallel list of policy, market, and educational interventions that are likely to precipitate and sustain the management activities suggested here.

In conclusion, we present a thorough list of management interventions to maintain or enhance regulating ecosystem services. We argue that the list represents an important stage in the decisionmaking process for, in this case, natural resource and ecosystem management. It should form a basis for review and assessment of the available evidence on the effectiveness, cost-effectiveness, and applicability of different options, a stage that should be carried out separately for given contexts, scales, and locations.

Although we have limited our solution scan here to regulating ecosystem services, the same process could be carried out for the other classes of ecosystem services: provisioning, supporting, and cultural. We suggest that solution scanning could be adopted more widely, covering many environmental issues. These might range, for example, from how to reduce forest loss and degradation to how to enhance food security. Equally, the methodology might be applied in other areas of policy, such as improving road safety, education or reducing the impact of recreational drugs on society.

Responses to this article can be read online at: http://www.ecologyandsociety.org/issues/responses. php/6082

\section{Acknowledgments:}

This activity was initiated as part of the Cambridge Conservation Initiative. We thank Abi Burns, Rob Cunningham, Peter Daszak, Gethin Davies, Benedict Gove, and Birgitta Rämert for input. The research was partly funded by RELU (RES 240-25-006), Arcadia, NERC (Biodiversity and Ecosystem Service Sustainability Directorate, NE/F01614X/1, NE/K001191/1 and NE/J500665/1), SAPES (Multifunctional Agriculture: Harnessing Biodiversity for Sustaining Agricultural Production and Ecosystem Services), and FORMAS (the Swedish Research Council for Environment, Agricultural Sciences and Spatial Planning).

\section{LITERATURE CITED}

Barton, D. N., D. P. Faith, G. M. Rusch, H. Acevedo, L. Paniagua, and M. Castro. 2009. Environmental service payments: evaluating biodiversity conservation trade-offs and cost-efficiency in the Osa Conservation Area, Costa Rica. Journal of Environmental Management 90:901-911.

Bateman, I. J., A. R. Harwood, G. M. Mace, R. T. Watson, D. J. Abson, B. Andrews, A. Binner, A. Crowe, B. H. Day, S. Dugdale, C. Fezzi, J. Foden, D. Hadley, R. Haines-Young, M. Hulme, A. Kontoleon, A. A. Lovett, P. Munday, U. Pascual, J. Paterson, G. Perino, A. Sen, G. Siriwardena, D. van Soest, and M. Termansen. 2013. Bringing ecosystem services into economic decisionmaking: land use in the United Kingdom. Science 341:45-50.

Beaumont, N. J., M. C. Austen, J. P. Atkins, D. Burdon, S. Degraer, T. P. Dentinho, S. Derous, P. Holm, T. Horton, E. van Ierland, A. H. Marboe, D. J. Starkey, M. Townsend, and T. Zarzycki. 2007. Identification, definition and quantification of goods and services provided by marine biodiversity: implications for the ecosystem approach. Marine Pollution Bulletin 54:253-265.

Bennett, E. M., G. D. Peterson, and L. J. Gordon. 2009. Understanding relationships among multiple ecosystem services. Ecology Letters 12:1394-1404. http://dx.doi.org/10.1111/ j.1461-0248.2009.01387.X

Bradbury, R. B., C. Stoate, and J. R. B. Tallowin. 2010. Lowland farmland bird conservation in the context of wider ecosystem service delivery. Journal of Applied Ecology 47:986-993. http://dx. doi.org/10.1111/j.1365-2664.2010.01843.X

Bryan, B. A. 2010. Development and application of a model for robust, cost-effective investment in natural capital and ecosystem services. Biological Conservation 143:1737-1750.

Burkhard, B., F. Kroll, S. Nedkov, and F. Muller. 2012. Mapping ecosystem service supply, demand and budgets. Ecological Indicators 21:17-29.

Carpenter, S. R., E. M. Bennett, and G. D. Peterson. 2006. Scenarios for ecosystem services: an overview. Ecology and Society 11(1): 29. [online] URL: http://www.ecologyandsociety. org/vol11/iss1/art29/

Chan, K. M. A., M. R. Shaw, D. R. Cameron, E. C. Underwood, and G. C. Daily. 2006. Conservation planning for ecosystem services. PLOS Biology 4:2138-2152. 
Chisholm, R. A. 2010. Trade-offs between ecosystem services: water and carbon in a biodiversity hotspot. Ecological Economics 69:1973-1987.

Daily, G. C., T. Soderqvist, S. Aniyar, K. Arrow, P. Dasgupta, P. R. Ehrlich, C. Folke, A. Jansson, B. O. Jansson, N. Kautsky, S. Levin, J. Lubchenco, K. G. Maler, D. Simpson, D. Starrett, D. Tilman, and B. Walker. 2000. Ecology - the value of nature and the nature of value. Science 289:395-396.

Defra. 2011. Biodiversity 2020: a strategy for England's wildlife and ecosystem services. COM 244 final, Department for Environment, Food and Rural Affairs (DEFRA), London, UK.

Dicks, L. V., I. Hodge, N. Randall, J. P. W. Scharlemann, G. M. Siriwardena, H. G. Smith, R. K. Smith, and W. J. Sutherland. 2013. A transparent process for "evidence-informed" policy making. Conservation Letters Online Early View.

Dicks, L. V., D. A. Showler, and W. J. Sutherland. 2010. Bee conservation: evidence for the effects of interventions. First edition. Pelagic Publishing, Exeter, UK.

Dominati, E., M. Patterson, and A. Mackay. 2010. Response to Robinson and Lebron: Learning from complementary approaches to soil natural capital and ecosystem services. Ecological Economics 70:139-140.

Dye, P. J. 1996. Climate, forest and streamflow relationships in South African afforested catchments. Commonwealth Forestry Review 75:31-38.

European Commission. 2011. Our life insurance, our natural capital: an EU biodiversity strategy to 2020. COM 244 final, European Commission, Brussels, Belgium.

Fisher, B., R. B. Bradbury, J. E. Andrews, M. Ausden, S. BenthamGreen, S. M. White, and J. A. Gill. 2011. Impacts of species-led conservation on ecosystem services of wetlands: understanding co-benefits and tradeoffs. Biodiversity and Conservation 20:24612481 .

Fisher, B., and R. K. Turner. 2008. Ecosystem services: classification for valuation. Biological Conservation 141:11671169.

Fisher, B., R. K. Turner, and P. Morling. 2009. Defining and classifying ecosystem services for decision making. Ecological Economics 68:643-653.

Gulickx, M. M. C., P. H. Verburg, J. J. Stoorvogel, K. Kok, and A. Veldkamp. 2013. Mapping landscape services: a case study in a multifunctional rural landscape in The Netherlands. Ecological Indicators 24:273-283.

Haaland, C., G. Fry, and A. Peterson. 2011. Designing farmland for multifunctionality. Landscape Research 36:41-62.

Hassan, R., R. Scholes, and N. Ash, editors. 2005. Ecosystems and human well-being: findings of the Conditions and Trends Working Group of the Millenium Ecosystem Assessment. Island Press, Washington, D.C., USA.

Hodgson, J. A., W. E. Kunin, C. D. Thomas, T. G. Benton, and D. Gabriel. 2010. Comparing organic farming and land sparing: optimizing yield and butterfly populations at a landscape scale. Ecology Letters 13:1358-1367.
Jacquet, J., I. Boyd, J. T. Carlton, H. Fox, A. E. Johnson, L. Mee, J. Roman, M. Spalding, and W. J. Sutherland. 2011. Scanning the oceans for solutions. Solutions 2:46-55.

Jasanoff, S. 1994. The fifth branch: science advisers as policymakers. Harvard University Press, Cambridge, Massachusetts, USA.

Kareiva, P., H. Tallis, T. H. Ricketts, G. C. Daily, and S. Polasky, editors. 2011. Natural capital: theory and practice of mapping ecosystem services. Oxford University Press, Oxford, UK.

Kremen, C., and A. Miles. 2012. Ecosystem services in biologically diversified versus conventional farming systems: benefits, externalities, and trade-offs. Ecology and Society 17: 40. [online] URL: http://www.ecologyandsociety.org/vol17/iss4/ art40/ http://dx.doi.org/10.5751/ES-05035-170440

Lawton, J. H. 2007. Ecology, politics and policy. Journal of Applied Ecology 44:465-474. http://dx.doi.org/10.1111/ j.1365-2664.2007.01315.x

Laycock, H., D. Moran, J. Smart, D. Raffaelli, and P. White. 2009. Evaluating the cost-effectiveness of conservation: the UK Biodiversity Action Plan. Biological Conservation 142:3120 3127.

Loreau, M. 2010. Linking biodiversity and ecosystems: towards a unifying ecological theory. Philosophical Transactions of the Royal Society B-Biological Sciences 365:49-60. http://dx.doi. org/10.1098/rstb.2009.0155

Martin, T. G., M. A. Burgman, F. Fidler, P. M. Kuhnert, S. LowChoy, M. Mcbride, and K. Mengersen. 2012. Eliciting expert knowledge in conservation science. Conservation Biology 26:2938 .

Munroe, R., D. Roe, N. Doswald, T. Spencer, I. Moller, B. Vira, H. Reid, A. Kontoleon, A. Giuliani, I. Castelli, and J. Stephens. 2012. Review of the evidence base for ecosystem-based approaches for adaptation to climate change. Environmental Evidence 1:13. http://dx.doi.org/10.1186/2047-2382-1-13

Nelson, E., G. Mendoza, J. Regetz, S. Polasky, H. Tallis, D. R. Cameron, K. M. A. Chan, G. C. Daily, J. Goldstein, P. M. Kareiva, E. Lonsdorf, R. Naidoo, T. H. Ricketts, and M. R. Shaw. 2009. Modeling multiple ecosystem services, biodiversity conservation, commodity production, and tradeoffs at landscape scales. Frontiers in Ecology and the Environment 7:4-11. http://dx.doi. org/10.1890/080023

Nemec, K. T., and C. Raudsepp-Hearne. 2013. The use of geographic information systems to map and assess ecosystem services. Biodiversity and Conservation 22:1-15

Pe'er, G., J. A. McNeely, M. Dieterich, B. G. Jonsson, N. Selva, J. M. Fitzgerald, and C. Nesshover. 2013. IPBES: Opportunities and challenges for SCB and other learned societies. Conservation Biology 27:1-3.

Pilgrim, E. S., C. J. A. Macleod, M. S. A. Blackwell, R. Bol, D. V. Hogan, D. R. Chadwick, L. Cardenas, T. H. Misselbrook, P. M. Haygarth, R. E. Brazier, P. Hobbs, C. Hodgson, S. Jarvis, J. Dungait, P. J. Murray, and L. G. Firbank. 2010. Interactions among agricultural production and other ecosystem services 
delivered from European temperate grassland systems. Advances in Agronomy 109:117-154.

Posthumus, H., J. R. Rouquette, J. Morris, D. J. G. Cowing, and T. M. Hess. 2010. A framework for the assessment of ecosystem goods and services; a case study on lowland floodplains in England. Ecological Economics 69:1510-1523.

Prato, T. 1999. Multiple attribute decision analysis for ecosystem management. Ecological Economics 30:207-222.

Pullin, A. S., W. J. Sutherland, T. Gardner, V. Kapos, and J. E. Fa. 2013. Conservation priorities: identifying need, taking action and evaluating success. Pages 3-22 in D. W. Macdonald, editor. Topics in conservation. Oxford University Press, Oxford, UK.

Raudsepp-Hearne, C., G. D. Peterson, and E. M. Bennett. 2010. Ecosystem service bundles for analyzing tradeoffs in diverse landscapes. Proceedings of the National Academy of Sciences of the United States of America 107:5242-5247. http://dx.doi. org/10.1073/pnas.0907284107

Reyers, B., P. J. O'Farrell, J. L. Nel, and K. Wilson. 2012. Expanding the conservation toolbox: conservation planning of multifunctional landscapes. Landscape Ecology 27:1121-1134.

Robinson, D. A., and I. Lebron. 2010. On the natural capital and ecosystem services of soils. Ecological Economics 70:137-138.

Sarewitz, D. 2000. Science and environmental policy: an excess of objectivity. Pages 79-98 in R. Frodeman, editor. Earth matters: the earth sciences, philosophy, and the claims of community. Prentice Hall, Upper Saddle River, New Jersey, USA.

Schultz, L., C. Folke, and P. Olsson. 2007. Enhancing ecosystem management through social-ecological inventories: lessons from Kristianstads Vattenrike, Sweden. Environmental Conservation 34:140-152.

Seppelt, R., C. F. Dormann, F. V. Eppink, S. Lautenbach, and S. Schmidt. 2011. A quantitative review of ecosystem service studies: approaches, shortcomings and the road ahead. Journal of Applied Ecology 48:630-636. http://dx.doi.org/10.1111/j.1365-2664.2010.01952. $\underline{\mathrm{x}}$

Seppelt, R., B. Fath, B. Burkhard, J. L. Fisher, A. Gret-Regamey, S. Lautenbach, P. Pert, S. Hotes, J. Spangenberg, P. H. Verburg, and A. P. E. van Oudenhoven. 2012. Form follows function? Proposing a blueprint for ecosystem service assessments based on reviews and case studies. Ecological Indicators 21:145-154.

Sutherland, W. J., S. D. Albon, H. Allison, S. Armstrong-Brown, M. J. Bailey, T. Brereton, I. L. Boyd, P. Carey, J. Edwards, M. Gill, D. Hill, I. Hodge, A. J. Hunt, W. J. F. Le Quesne, D. W. Macdonald, L. D. Mee, R. Mitchell, T. Norman, R. P. Owen, D. Parker, S. V. Prior, A. S. Pullin, M. R. W. Rands, S. Redpath, J. Spencer, C. J. Spray, C. D. Thomas, G. M. Tucker, A. R. Watkinson, and A. Clements. 2010. The identification of priority policy options for UK nature conservation. Journal of Applied Ecology 47:955-965. http://dx.doi.org/10.1111/j.1365-2664.2010.01863.x
Sutherland, W. J., J. A. Alves, T. Amano, C. H. Chang, N. C. Davidson, C. M. Finlayson, J. A. Gill, R. E. Gill, P. M. Gonzalez, T. G. Gunnarsson, D. Kleijn, C. J. Spray, T. Szekely, and D. B. A. Thompson. 2012. A horizon scanning assessment of current and potential future threats to migratory shorebirds. Ibis 154:663-679. http://dx.doi.org/10.1111/j.1474-919X.2012.01261.x

Sutherland, W. J., S. Bardsley, M. Clout, M. H. Depledge, L. V. Dicks, L. Fellman, E. Fleishman, D. W. Gibbons, B. Keim, F. Lickorish, C. Margerison, K. A. Monk, K. Norris, L. S. Peck, S. V. Prior, J. r. P. W. Scharlemann, M. D. Spalding, and A. R. Watkinson. 2013. A horizon scan of global conservation issues for 2013. Trends in Ecology \& Evolution 28:16-22.

Sutherland, W. J., E. Fleishman, M. B. Mascia, J. Pretty, and M. A. Rudd. 2011a. Methods for collaboratively identifying research priorities and emerging issues in science and policy. Methods in Ecology and Evolution 2:238-247.

Sutherland, W. J., D. Goulson, S. G. Potts, and L. V. Dicks. 2011b. Quantifying the impact and relevance of scientific research. PLoS ONE 6(11): e27537. doi:10.1371/ journal.pone.0027537. http:// dx.doi.org/10.1371/

Sutherland, W. J., A. S. Pullin, P. M. Dolman, and T. M. Knight. 2004. The need for evidence-based conservation. Trends in Ecology and Evolution 19:305-308.

The Economics of Ecosystems and Biodiversity (TEEB). 2010. The economics of ecosystems and biodiversity: mainstreaming the economics of nature: a synthesis of the approach, conclusions and recommendations of TEEB. United Nations Environment Programme, Nairobi, Kenya.

Turner, R., S. Georgiou, and B. Fisher. 2008. Valuing ecosystem services: the case of multi-functional wetlands. Earthscan, Washington, D.C., USA.

UK National Ecosystem Assessment. 2011. The UK National Ecosystem Assessment technical report. UNEP-WCMC, Cambridge, UK.

Williams, D. R. R. G. Pople, D. A. Showler, L. V. Dicks, M. F. Child, E. K. H. J. zu Ermgassen, and W. J. Sutherland. 2013. Bird Conservation - evidence for the effects of interventions. Pelagic Publishing, Exeter, UK.

World Bank. 2012. Moving beyond GDP. How to factor natural capital into economic decision making. Wealth accounting and valuation of ecosystem services (WAVES). The World Bank, Washington, D.C., USA.

Zhang, W., T. H. Ricketts, C. Kremen, K. Carney, and S. M. Swinton. 2007. Ecosystem services and dis-services to agriculture. Ecological Economics 64:253-260. 
Appendix 1. List of management interventions for maintaining or enhancing regulating ecosystem services

\section{AIR QUALITY REGULATION}

This section considers interventions to maintain non-climate related services concerned with air quality, including the extraction of chemicals such as particulates and direct air contaminants, and the emission of chemicals, such as oxygen.

\section{Forests}

1. Protect and expand forested area to absorb gaseous pollutants and trap particulates.

\section{Coastal}

2. Maintain vegetation in coastal wetlands, especially mangrove systems, to absorb gaseous pollutants and trap particulates.

\section{Agricultural land}

3. Plant shelter belts to absorb gaseous pollutants, intercept aerosols from pesticides and trap particulates.

4. Use soil conservation measures (such as cover crops, wind breaks and minimum or conservation tillage) to reduce wind erosion and hence airborne particulates.

\section{Urban}

5. Protect urban green spaces, to absorb gaseous pollutants and trap particulates.

\section{CLIMATE REGULATION}

This section covers interventions relating to the control of greenhouse gases (particularly carbon dioxide, methane and nitrous oxide), through reducing emissions and/or enhancing removal of such gases from the atmosphere. It incorporates more local climatic controls, such as ecosystem controls over temperature or precipitation. Ecosystem services relating to impacts of climate change such as storm surges and sea level rise are considered under natural hazard regulation.

\section{Forests}

6. Protect the area and condition of existing forest areas from clearing and degradation from logging, fire and unsustainable levels of non-timber resource extraction.

7. Adopt reduced impact logging techniques (including logging inventories, directional felling, liana clearance, low-impact extraction techniques, retention of roots, off-cuts and dead wood) in forestry operations to reduce collateral damage from timber extraction.

8. Reforest degraded land and encourage benign abandonment of low productivity or disused land.

9. Encourage enrichment planting in degraded and regenerating forests.

\section{Terrestrial wetlands}

10. Maintain and enhance natural wetlands.

11. Install dams in drains to restore degraded peatlands and avoid further drainage of undisturbed areas.

12. Re-vegetate bare peat to prevent oxidation. 
13. Use geo-textiles to arrest peat erosion.

14. Practise controlled removal of peatland vegetation or use appropriate grazing to reduce the risk of wild-fire.

15. Avoid planting forests on peat.

16. Limit use of fire in agriculture on or near peat soils.

17. Avoid over-grazing of vegetation.

\section{Coastal}

18. Protect remaining intertidal muds, saltmarshes and mangrove communities, seagrass beds and vegetated dunes from further degradation, fragmentation and loss.

19. Re-establish and restore previous intertidal habitat by de-poldering or coastal realignment.

20. Prohibit new aquaculture developments in intertidal areas.

21. Restore micro-topography, creek networks, sediment inputs and nutrient exchange in abandoned aquaculture ponds.

22. Create new intertidal habitat through planting of mangroves, saltmarsh or seagrass at appropriate elevations in the tidal frame.

23. Enhance or facilitate habitat expansion, including the facilitated range expansion of mangroves, as warming conditions and changes in storminess permit.

24. Establish appropriate levels of saltmarsh grazing pressure to stimulate below-ground biomass production and carbon uptake.

25. Encourage development of early successional sand dune habitats (dry dunes and wet slacks) where carbon sequestration rates are high.

26. Restore or enhance sediment supplies from riverine or coastal sources to encourage carbon sequestration by coastal wetlands.

\section{Marine}

27. Fertilise oceans to increase carbon removal and deep ocean storage through enhanced phytoplankton productivity.

\section{Agricultural land}

28. Use soil conservation measures (such as cover crops, wind breaks, deep-rooted plants and minimum or conservation tillage) to enhance storage of soil carbon.

29. Produce and integrate biochar into agricultural soils.

30. Reduce management intensity on permanent grassland (in particular reduce fertilizer inputs) to promote botanically-diverse swards and enhance carbon sequestration to soil.

31. Promote inter-cultivation in perennial and agroforestry cropping systems with deeper rooting systems that create carbon stocks.

32. Provide herbicide-free strips in orchards and vineyards to increase carbon sequestration.

33. Reintroduce or enhance populations of deep-burrowing (anecic) worms to help sequester carbon.

34. Increase soil organic matter by incorporating green manure, slurry or incorporating crop residues to enhance carbon storage.

35. Reduce stocking rates of livestock.

36. Grow crops with a lower harvest index so more biogenic carbon is returned to the soil

37. In seasonal environments use supplementary animal feed from on-farm crops, such as maize 
and sugar cane, to reduce soil erosion.

38. Use sub-soil drainage to reduce emissions of nitrous oxide from wet soils.

39. Adjust soil $\mathrm{pH}$ and add lime to enhance organic storage.

40. Reduce use of chemical pesticides that have adverse effects on soil microflora.

41. Avoid conversion of permanent grassland to arable.

Urban

42. Protect urban green spaces to store carbon.

\section{WATER FLOW REGULATION}

Interventions that support the role of ecosystems in altering the magnitude and timing of water runoff and flooding as well as the recharge of aquifers (see also natural hazard regulation for regulator services linked to coastal defence and flooding).

Forests

43. Limit use of heavy machinery in forestry operations to avoid soil compaction.

44. Retain forest cover on steep slopes.

45. Avoid felling operations during rainy seasons

46. Switch plantation forests from coniferous to deciduous to reduce acidification.

47. Plant forests at lower densities.

48. Practise alternatives to clearfell, such as continuous cover forestry.

\section{Terrestrial Wetlands}

49. Maintain and enhance natural wetlands.

50. Restore wetlands in areas of groundwater recharge.

51. Re-vegetate bare peat to increase surface roughness.

52. Use geo-textiles to arrest peat erosion.

53. Reconnect rivers with floodplains to enhance natural water storage.

\section{Freshwater}

54. Encourage re-vegetation of riverbanks (such as through livestock exclusion, and/or direct planting).

55. Restore riparian vegetation to assist in reconnecting rivers with floodplains and to provide greater instream ecosystem complexity.

56. Increase up-stream structural diversity (such as through the re-introduction of beavers).

57. Reduce canalisation and create channel diversity to reduce speed of flood transmission.

58. Re-meander rivers (where they have been artificially straightened) to help reduce speed and height of flood peaks.

\section{Coastal}

59. Re-connect river systems to coastal wetlands through controlled breaching of river levees or construction of river control structures that allow periodic flooding of wetlands.

\section{Agricultural land}

60. Use soil conservation measures (such as cover crops, wind breaks, deep-rooted plants and minimum or conservation tillage) to increase soil structure and infiltration rates. 
61. Increase soil organic matter by incorporating green manure, slurry or incorporating crop residues to increase water infiltration (although high quantities of soil organic matter can lead to soil complexes with impeded drainage).

62. Reduce soil-water repellency (e.g. avoid burning, and enhance soil microbial activity) to limit run-off and increase soil-water capture.

63. Plant trees / hedges /perennial grass strips to intercept surface run-off.

64. Reduce stocking rates of livestock.

65. Reduce soil compaction by machinery, by reducing machinery use, using lighter machinery, low pressure tyres or controlled traffic techniques

66. Alleviate soil compaction by sub-soiling.

67. Plant biomass crops in locations where they can enhance water interception (such as slopes).

68. Increase average sward heights in pasture to reduce surface run-off, perhaps by adjusting stock type or density.

69. Use cultivars with deeper rooting systems to maximise rainfall use.

70. Balance the use of evergreen and deciduous trees to enhance seasonal water regulation.

71. Modify cultivation practices (e.g. siting of animal feed sites, ploughing regimes) to avoid ready downslope transfer and loss of water.

72. Reduce use of chemical fertilisers where they reduce soil organic matter.

\section{Urban}

73. Plant green roofs to encourage interception of rainfall.

74. Establish rain gardens (planted depressions or swales allowing runoff from impervious urban areas to be absorbed).

75. Greater use of balancing ponds to contain surges and release slowly.

76. Use underground water storage systems.

\section{EROSION REGULATION}

Interventions to maintain restore or enhance the role of ecosystems in reducing erosion of soil and sediments and in encouraging maintenance or growth of the same.

\section{Forests}

77. Retain and restore forest cover on steep slopes.

78. Retain vegetation on margins of water courses.

79. Limit use of heavy machinery in forestry operations.

80. Carry out felling or forest clearance at appropriate seasons.

81. Leave leaf litter and dead wood on the forest floor, prohibit or limit salvage logging.

82. Practise alternatives to clearfell, such as continuous cover forestry.

\section{Terrestrial wetlands}

83. Install small dams in surface drains to prevent eroded material leaving peatlands.

84. Re-vegetate bare peat to prevent peat oxidation.

85. Use geo-textiles to arrest peat erosion.

86. Practise controlled removal of vegetation to reduce the risk of wild-fire. 


\section{Freshwater}

87. Encourage re-vegetation of riverbanks (such as through stock exclusion, and/or direct planting).

88. Increase up-stream structural diversity.

89. Re-establish and/or encourage beaver populations.

90. Reduce canalisation and create channel diversity.

91. Manage sediment problems (fine and coarse) at source (e.g. on agricultural land) rather than through dredging.

92. Replace hard engineered river stabilisation with softer alternatives (e.g. willow-based).

93. Allow for natural erosion processes rather than trying to prevent them (e.g. set back river defences and allow natural river migration within the defence line).

\section{Coastal}

94. Protect remaining intertidal muds, saltmarshes and mangrove communities, seagrass beds and vegetated dunes from further degradation, fragmentation and loss.

95. Re-establish and restore previous intertidal habitat by depoldering or coastal realignment to increase resilience to wind and storm waves.

96. Encourage increased use of mangroves within and around existing extensive tropical aquaculture ponds.

97. Retain coastal forest and beachridge vegetation to minimize sedimentation problems on nearby reefs.

98. Create new intertidal habitat through afforestation, or planting of saltmarsh or seagrass at appropriate elevations in the tidal frame.

99. Maintain, restore and create coastal wetlands of sufficient areal extent to allow natural cycles of erosion/sedimentation to compensate one another within the wetland complex.

100. Re-connect river systems to coastal wetlands through breaching of river levees or river control structures to re-introduce river sediments to coastal wetlands.

101. Introduce dredged spoil material from estuarine waterways to coastal wetland surfaces.

102. Allow erosion of soft rock cliffs (cease armouring and stabilization), coupled to un-interrupted alongshore sediment transport, to supply coarse sediments to beaches and offshore banks and fine sediments to coastal wetlands.

103. Allow natural alongshore dynamics of large-scale coastal sediment accumulations (nesses, spits and cuspate forelands). Assist if necessary with sand and gravel by-passing and re-charge operations.

104. Use beach nourishment (repetitive artificial replenishment of beaches) to rebuild eroding beaches.

105. Maintain dunes and the beaches fronting them, in part by allowing sediment exchange across beach-dune boundaries.

106. Actively repair and construct sand dunes.

107. Adopt measures for topsoil inversion and deliberate dune destabilization (including introduction of appropriate grazing levels) to rejuvenate stabilized dune systems.

108. Control groundwater abstraction that affects water and nutrient flows through wetlands and accelerates subsidence.

109. Reduce direct threats to biogenic reefs (notably coral reefs, but also shellfish, vermitid and algal reefs) from unsustainable fishing practises.

110. Reduce proximate and remote threats to reefs from watersheds through appropriate 
measures to minimize agricultural chemicals, livestock waste, urban and industrial effluents entering rivers and estuaries.

111. Restore or create shellfish reefs in coastal locations where they may enhance sediment deposition

112. Restore or enhance coral reef growth or recovery using artificial substrates, electro-accumulation or coral transplantation at reef scales.

113. Avoid construction work in tropical wet seasons to minimize excessive terrestrial sediment inputs into the nearshore zone.

114. Control anchoring through provision of fixed moorings and anchorage zones in areas of soft sediments to reduce structural damage to reefs.

115. Locate access channels through reefs to minimize impact on reef hydrodynamics and sediment transport.

\section{Agricultural land}

116. Encourage ploughing across rather than down slopes subject to floods.

117. Use strip tillage.

118. Plant cover crops in inter-row strips.

119. Maintain permanent plant or crop residue cover.

120. Use minimal tillage / direct drilling to increase soil structure and infiltration rates.

121. Avoid harvesting in wet conditions.

122. Reduce soil compaction by machinery, by reducing machinery use, using lighter machinery, low pressure tyres or controlled traffic techniques.

123. Plant trees / hedges /perennial grass strips to intercept surface run-off.

124. Provide livestock with hard-standing access to watercourses to prevent erosion of stream-banks.

125. Provide livestock with water pumped to troughs set away from water bodies, to prevent erosion of stream-banks.

126. Reduce stocking rates of livestock (e.g. through pasture rotation) and consider timing of grazing, to prevent over-grazing.

127. Control over-abundant wildlife to reduce competition for grazing and overall grazing pressure.

128. Encourage soil management practices to develop surface-vented macropores to trap surface-ponded and reduce runoff by routing water into the rootzone.

129. Include buffer strips and site farm gates to prevent eroded material leaving fields.

130. Install small dams in ditch systems, to prevent eroded material leaving farmland.

\section{Urban}

131. Use phytoremediation and phytostabilisation on contaminated sites.

132. Use of permeable surfaces and vegetation where possible in hard landscape construction.

\section{WATER PURIFICATION AND WASTE TREATMENT}

Interventions to enhance the role of ecosystems in removing chemical and particulate compounds from the water, including the breakdown of toxic wastes and the assimilation of chemicals and particulates into soils or marine sediments. 


\section{Terrestrial Wetlands}

133. Use engineered reedbeds/wetlands for tertiary treatment of effluent.

134. Target ponds/wetland creation to trap sediment/pollution runoff in farmed landscape.

135. Create marginal wetlands to trap and/or cycle nutrients.

136. Dam to restore upland bogs to reduce dissolved and particulate organic carbon and coloured humic substances leaving catchments.

137. Replant wet woodland to provide enhanced nutrient uptake.

138. Re-vegetate bare peat.

\section{Coastal}

139. Protect remaining intertidal habitats, especially saltmarshes and mangroves,

140. Re-establish and restore previous intertidal habitat by depoldering or coastal realignment to reduce particulate contamination of water, eutrophication and toxic pollution in coastal waters.

141. Encourage increased use of mangroves within and around existing extensive tropical aquaculture ponds.

142. Restore or create shellfish reefs to restore active filtration of suspended sediments and removal of nitrates and other pollutants.

\section{Marine}

143. Use bioremediation at locations of intense pollution, notably oil spills, through nutrient amendment (biostimulation), bioaugmentation, photoremediation and oxygen enhancement.

\section{Agricultural land}

144. Plant trees/hedges/perennial grass strips to increase nutrient uptake.

145. Plant biomass crops in locations where they can enhance nutrient uptake.

146. Restore grassland/low input arable in drinking water catchments.

147. Intercrop with legumes.

148. Increase soil organic matter by incorporating green manure, slurry or incorporating crop residues to enhance carbon storage.

149. Produce and integrate biochar into agricultural soils.

150. Use hyper-accumulator phytoremediation plants to remove contaminants from the soil, or to reduce their bioavailability.

151. Reduce use of veterinary pharmaceutical products including antibiotics and hormone regulators/growth promoters.

\section{Urban}

152. Create ponds and wetlands to collect, store and clean water before gradual release into water courses (Sustainable Urban Drainage Systems).

153. Reduce output and improve treatment of industrial and municipal effluent through biodegradation and bioconversion.

154. Improve remediation of wastes before disposal in soil or water by greater use of biological, physical and chemical methods.

155. Improve treatment of contaminated land through phytoremediation. 


\section{DISEASE REGULATION}

Following the Millennium Ecosystem Assessment, this section covers regulation of human infectious diseases, hosts and vectors. We used the criteria: does this intervention enhance or protect the capacity of the ecosystem to regulate human diseases? Interventions to enhance regulation of diseases of crops and trees are included under Pest Regulation.

\section{Forests}

156. Remove invasive plants, with particular attention to those that are favourable environments for ticks and other vectors.

157. Protect and expand forested area to maintain species diversity in order to reduce disease transmission either via predator-mediated control or dilution of competent hosts.

158. Construct habitat corridors to promote predator populations over large areas in order to regulate host populations.

\section{Coastal}

159. Maintain vegetation in coastal wetlands, especially mangrove systems, to trap particulates.

\section{Agricultural land}

160. Reduce use of veterinary pharmaceutical products including antibiotics and hormone regulators/growth promoters.

161. Use soil conservation measures (such as cover crops, wind breaks and minimum or conservation tillage) to reduce wind erosion and hence airborne particulates.

162. Reduce stocking rates of livestock to minimise opportunity for pathogen spillover and pressures on virulence/selection.

163. Plant fruit trees or provide other forms of roosting and feeding habitat (for bats) away from livestock areas in order to minimise transmission opportunities

164. Reduce agrichemical inputs to reduce development of pest resistance and to maintain biodiversity in target and non-target systems, especially aquatic systems.

165. Provide bat houses and bird feeders to promote establishment of species for mosquito (or other insect vector) regulation.

166. Improve the connectivity of non-crop habitats to enhance dispersal of predators of disease host species.

167. Decrease the level of land-use intensity in the landscape, e.g. through large-scale conversion to organic farming.

168. Reduce sources of standing water and hence limit the establishment of vector populations.

\section{Urban}

169. Reduce output and improve treatment of industrial and municipal effluent through biodegradation and bioconversion.

170. Improve remediation of wastes before disposal in soil or water by greater use of biological, physical and chemical methods. 
171. Protect urban green spaces to encourage biodiversity and the establishment of vector-feeding species, in particular.

172. Use permeable surfaces and vegetation where possible in hard landscape construction in order to reduce sources of standing water and limit the establishment of vector populations.

173. Provide bat houses, and bird feeders and housing, to promote establishment of species for mosquito (or other insect vector) regulation.

\section{PEST REGULATION}

Interventions to enhance the role of ecosystems in reducing the damage to crops and livestock caused by pests and diseases. The interventions listed for each habitat type consider regulation of pests or diseases causing damage within that habitat type, but includes interventions both within that habitat and in the surrounding landscape.

Forests

174. Reduce use of insecticides (especially broad spectrum) to maintain abundance and diversity of natural enemies and alternative hosts for entomopathogens.

175. Increase resistance of trees by forest management (e.g. thinning for bark beetle pests).

176. Use natural regeneration with seed trees.

177. Practise continuous cover forestry.

178. Promote mixed tree species stands to increase diversity of natural enemies and to reduce density of host trees for pests.

179. Promote deciduous trees, repellent for conifer insect pests and preferred as food by browsing herbivores, in conifer stands.

180. Avoid high proportion of susceptible age classes of forest stands at the landscape level (e.g. over-mature conifer stands susceptible to bark beetle attacks).

181. Use dispensers releasing attractants to enhance densities of natural enemies and competitors at attacked trees or stands.

182. Enhance densities of generalist natural enemies, and competitors, by providing breeding substrates exclusively utilized by non-pest prey species (e.g. tree species or parts of cut trees).

183. Avoid sanitation cutting of trees from which pests have emerged while natural enemies remain.

184. Avoid thinning to reduce the risk of infestation of the stand by pathogens (e.g. root rot).

185. Plant a diverse range of nectar and pollen-providing plants (including shrubs) to increase efficacy of omnivorous natural enemies.

186. Use food spray to increase efficacy of omnivorous natural enemies.

187. Release native natural enemies or competitors (augmentative biological control) to increase their population sizes.

188. Favour large predators (e.g. by reducing hunting) to reduce populations of browsing herbivores.

\section{Agricultural land}

189. Create grass margins / beetle banks to promote predatory invertebrates.

190. Leave field margins unsprayed and uncropped. 
191. Divide crops into smaller areas.

192. Increase the perimeter-to-area ratio of agricultural fields to facilitate spillover of natural enemies of agricultural pests.

193. Rotate crops to reduce build up of crop-specific pests and pathogens.

194. Deploy flower strips, or plants with extra-floral nectaries to promote omnivorous natural enemies (e.g. parasitoids and hoverflies).

195. Use mulching to provide shelter and alternative food for natural enemies, and to suppress weeds.

196. Intercrop with plants that repel or confuse pests and/or attract natural enemies and that reduce dispersal of pathogen propagules.

197. Plant a trap crop that is more attractive to the pest than the crop.

198. Use push-pull technique: combining plants repellent for the pest within the field with attractive plants (trap crop) around the field.

199. Conduct periodic harvesting, leaving strips of the crop as refuges for natural enemies.

200. Plant a cover crop that maintain populations of natural enemies in the crop, make it more difficult for pests to locate crops, reduce dispersal of plant pathogens and suppress weeds.

201. Reduce tillage to conserve soil-dwelling natural enemies.

202. Reduce use of insecticides (especially broad spectrum), to maintain abundance and diversity of natural enemies and alternative hosts for entomopathogens.

203. Reduce herbicide use to increase the availability of nectar, pollen and alternative prey for natural enemies of agricultural pests.

204. Provide bird perches for predatory birds to rest and to look for prey.

205. Ploughing under of live (green manuring) and dead organic material to provide shelter and alternative food for natural enemies of pests and to make the soil more suppressive against plant pathogens.

206. Provide holes in the soil to enhance habitat for spiders.

207. Practise timely cutting of non-crop plants utilized by natural enemies (for food, shelter etc) to encourage dispersal into the crop.

208. Use dispensers releasing attractants to enhance densities of natural enemies and competitors in the crop.

209. Use artificial food-sprays (carbohydrates and protein) to enhance food availability for natural enemies within the crop.

210. Release native natural enemies or competitors (augmentative biological control) to increase their population sizes.

211. Provide set-aside areas of natural habitat on farmland.

212. Increase heterogeneity in agricultural landscapes, including natural habitat remnants.

213. Improve landscape-scale connectivity between natural or non-crop habitat remnants to enhance dispersal of natural enemies of pests.

214. Increase the availability of shelter belts, hedgerows and other woody habitats in the landscape to provide habitat for natural enemies.

215. Manage hedges and habitat corridors to benefit natural enemies (keep unsprayed, fill gaps, plant flowering hedge plants).

216. Increase the availability of perennial crops in the landscape (e.g. through crop rotation with ley) to enhance natural enemies.

217. Decrease the level of land-use intensity in the landscape, e.g. through large-scale conversion to organic farming. 
218. Restore flower-rich natural habitats such as species-rich grassland in farmed areas (including linear sites such as road verges, beneath power lines or on field margins) to benefit omnivorous natural enemies of pests.

\section{POLLINATION}

Interventions to maintain or enhance biodiversity-mediated pollination

\section{Forests}

219. Protect existing areas of forest from further clearance or degradation

220. Restore natural forests through managed regeneration or benign abandonment.

221. Maintain areas with open under-storey and gaps in forests/woodland.

222. Protect large native trees.

223. Conserve dead and down trees as nesting sites.

\section{Agricultural land}

224. Restore flower-rich natural habitats such as species-rich grassland in farmed areas (including linear sites such as road verges, beneath power lines or on field margins).

225. Change intensity of grazing, cutting or burning to increase flowering.

226. Reduce shrub cover through grazing, cutting or burning.

227. Protect and enhance trees/hedges/perennial grass strips to provide suitable materials or vegetation for bee nesting and hibernation.

228. Provide set-aside areas of natural habitat on farmland.

229. Increase heterogeneity in agricultural landscapes, including natural habitat remnants.

230. Improve landscape-scale connectivity between natural or non-crop habitat remnants.

231. Manage hedges and habitat corridors to benefit pollinators (keep unsprayed, fill gaps, plant flowering hedge plants).

232. Protect bat roosts, where bats are important pollinators.

233. Create bare ground (well-drained) for ground-nesting bees.

234. Provide soft earth for bees to hibernate in.

235. Use drip- or spray irrigation rather than flooding.

236. Provide nest boxes or nest sites (drilled holes) for cavity-nesting solitary bees.

237. Reduce tillage (benefits ground-nesting bees).

238. Leave field margins unsprayed and uncropped.

239. Plant a diverse range of nectar and pollen-providing plants, as well as caterpillar food plants, and leguminous fallow crops, such as clover.

240. Reduce fertilizer, pesticide and herbicide use generally.

241. Reduce management intensity on permanent grassland (in particular reduce fertilizer inputs).

242. Restrict certain pesticides, such perhaps as neonicotinoids.

243. Apply pesticides at night.

244. Avoid applying pesticides during flowering.

245. Apply pesticides at ground level.

246. Avoid microencapsulated formulations that mimic pollen.

247. Keep bodies of water (ponds and ditches) pesticide-free to provide habitat for pollinating flies, water sources for bats and butterflies, and insect food for hummingbirds. 
Urban

248. Encourage planting of appropriate resource plants and caterpillar food plants in gardens and municipal areas.

249. Retain areas of rough ground or old built structures for nesting habitat.

\section{NATURAL HAZARD REGULATION}

Interventions to maintain, enhance or restore the ability of ecosystems to reduce the impacts of natural hazards including storm surges, hurricanes, floods, fires, tsunamis and the impact of rising sea levels.

\section{Forests}

250. Protect the area and condition of existing forest areas from clearing and degradation.

251. Impose strict limitations or bans on the use of fire to manage agricultural land adjoining forested areas.

252. Limit or carefully manage salvage logging to prevent dangerous build-up of fuel loads.

253. Reforest degraded land and encourage benign abandonment of low productivity or disused land.

254. Encourage enrichment planting in degraded and regenerating forests.

\section{Terrestrial wetlands}

255. Use wetlands to create emergency flood capacity.

256. Maintain and enhance natural wetlands.

257. Install small dams in surface drains to reduce hydraulic connectivity and improve habitat structure to slow overland flow.

258. Restore floodplain forest or other semi-natural features, such as wet grassland, to increase hydraulic roughness and so slow conveyance and enhance storage of floodplains.

259. Reconnect rivers with floodplains to enhance natural water storage.

260. Practise controlled removal of peatland vegetation or use appropriate grazing to reduce the risk of wild-fire.

261. Limit use of fire in agriculture on or near peat soils.

\section{Freshwater}

262. Encourage re-vegetation of riverbanks (such as through stock exclusion, and/or direct planting).

263. Restore riparian vegetation to assist in reconnecting rivers with floodplains and to provide greater instream ecosystem complexity.

264. Increase up-stream structural diversity (such as through the re-introduction of beavers, or restoring boulders and large woody debris in upland rivers) to increase flood interception potential.

265. Reduce canalisation and create channel diversity to reduce speed of flood transmission.

266. Re-meander rivers (where they have been artificially straightened) to help reduce speed and height of flood peaks. 
Coastal

267. Protect remaining intertidal muds, saltmarshes and mangrove communities, seagrass beds and vegetated dunes from further degradation, fragmentation and loss.

268. Re-establish and restore previous intertidal habitat by de-poldering or coastal realignment, to provide both renew defence against incident waves and enhance storm water storage.

269. Create new intertidal habitat through afforestation, or planting of saltmarsh or seagrass at appropriate elevations in the tidal frame.

270. Prioritise protection or restoration of mangroves in areas close to human settlement.

271. Set back estuarine defences to enhance storage to accommodate tidal surges.

272. Retain or acquire a coastal buffer zone to allow coastal barriers (gravel ridges, beaches and dunefields) to 'roll-over' landward under sea level rise and storms.

273. Introduce dredged spoil material from estuarine waterways to coastal wetland surfaces.

274. Allow erosion of soft rock cliffs (cease armouring and stabilization), coupled to un-interrupted alongshore sediment transport, to supply coarse sediments to beaches and offshore banks and fine sediments to coastal wetlands.

275. Allow natural alongshore dynamics of large-scale coastal sediment accumulations (nesses, spits and cuspate forelands). Assist if necessary with sand and gravel by-passing and re-charge operations.

276. Use beach nourishment (repetitive artificial replenishment of beaches) to rebuild eroding beaches.

277. Maintain dunes and the beaches fronting them, in part by allowing sediment exchange across beach-dune boundaries.

278. Actively repair and construct sand dunes.

279. Adopt measures for topsoil inversion and deliberate dune destabilization (including introduction of appropriate grazing levels) to rejuvenate stabilized dune systems.

280. Re-connect river systems to coastal wetlands through controlled breaching of river levees or use of river control structures to re-introduce river sediments to coastal wetlands.

281. Control groundwater abstraction that affects water and nutrient flows through wetlands and accelerates subsidence.

Agricultural land

282. Plant trees/hedges/perennial grass strips to intercept surface runoff.

283. Use minimal tillage / direct drilling to increase soil structure and infiltration rates.

284. Increase soil organic matter by incorporating green manure, slurry or incorporating crop residues to increase water infiltration.

285. Reduce soil-water repellency (e.g. avoid burning, and enhance soil microbial activity) to limit run-off and increase soil-water capture.

286. Reduce stocking rates of livestock.

287. Reduce soil compaction by farm machinery.

288. Alleviate soil compaction by sub-soiling.

289. Increase average sward heights in pasture to reduce surface run-off, perhaps by adjusting stock type or density.

290. Use cultivars with deeper rooting systems to maximise rainfall use and reduce runoff.

Urban

291. Increase use of Sustainable Urban Drainage Systems. 
292. Reduce garden paving.

293. Increase use of green roofs.

294. Increase tree planting in urban locations.

295. Increase use of balancing ponds and underground storage systems.

296. Use permeable surfaces in hard landscape construction to provide aquifer recharge. 